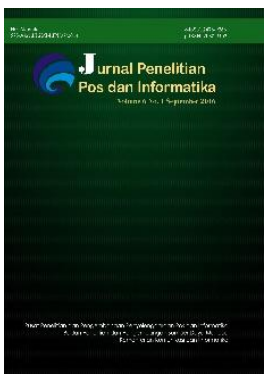

JPPI Vol 6 No 2 (2016) 185 - 200

Jurnal Penelitian Pos dan Informatika

578/AKRED/P2MI-LIPI/07/2014

e-ISSN 2476-9266

p-ISSN: 2088-9402

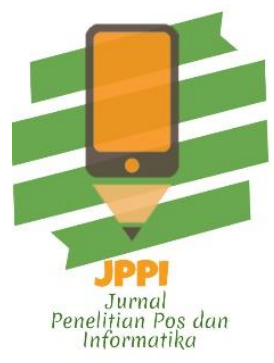

DOI : 10.17933/jppi.2016.060205

\title{
PEMANFAATAN TEKNOLOGI GOOLE MAPS API UNTUK APLIKASI LAPORAN KRIMINAL BERBASIS ANDROID PADA POLRESTABES MAKASSAR
}

\section{THE UTILIZATION GOOGLE MAPS API TECHNOLOGY FOR APPLICATION CRIMINAL REPORTS ANDROID IN POLRESTABES MAKASSAR}

\author{
Rismayani \\ Program Studi Sistem Informasi (STMIK Dipanegara Makassar) \\ J1. Perintis Kemerdekaan Kemerdekaan Km.9 Makassar, Tamalanrea Makassar 90000 Indonesia \\ maya_setya@ymail.com
}

Naskah diterima: 14 November 2016; direvisi: 27 Desember 2016; disetujui: 27 Desember 2016

\begin{abstract}
Abstrak
Polrestabes Makassar adalah institusi negara yang berada di bawah naungan kepolisian daerah Sulawesi Selatan yang memiliki tugas dan tanggung jawab untuk melayani masyarakat kota Makassar dalam proses penanganan berbagai macam permasalahan keamanan dan kriminalitas pada masyarakat kota Makassar. Adapun permasalahan pada penelitian ini adalah bagaimana masyarakat dapat melaporkan tindak kriminal yang terjadi di sekitar mereka tanpa harus datang ke kantor polisi dan bagaimana aparat dapat menerima langsung laporan kriminal dari masyarakat tanpa harus bertemu dan dapat melihat kejadian dari foto yang dikirimkan serta dapat mengetahui lokasi kejadian tindak kriminal di wilayah kota Makassar. Tujuan dari penelitian ini adalah membuat aplikasi berbasis android dengan memanfaatkan teknologi Google Maps API untuk mengirim laporan kriminal dalah bentuk foto serta mengirimkan lokasi kejadian tindak kriminal dari masyarakat ke aparat kepolisian. Adapun metode atau teknologi yang digunakan adalah Google Maps API dan berbasis Android. Hasil dari penelitian ini adalah dengan adanya aplikasi tersebut maka masyarakat dapat melaporkan tindak kriminal yang terjadi di sekitar mereka tanpa harus datang ke kantor polisi dan memudahkan para aparat kepolisian untuk melihat laporan kriminal dari masyarakat dengan melihat gambar dan lokasi kejadian kriminal.

Kata kunci: Google Maps API, Laporan Kriminal, Android

\section{Abstract}

Polrestabes Makassar is a state institutions under the shade of south sulawesi which have duties and responsibilities to serve a people of Makassar city in the process of handling a wide variety security issues and criminality in society a makassar city. The problem in this research is how the public can report criminal activity that is happening around them without going to the police and how the police can receive a direct criminal report from the society without having to meet and can look at incident from the photos submitted and can determine location of the incident criminal activity in the of Makassar City. The purpose from the research is to create a android based applications by utilizing the technology Google Maps API to send the criminal report in the form of images and send criminal activity scene from society to police officers. The method or technology used is Google Maps Api on Andori based. The Results from this research is by the existence application the society can a criminal activity report that is happening around them without going to the police station and easier for police officers to look at crime reports from the society to look at image and location of crime scene.
\end{abstract}

Keywords: Google Maps API, Criminal Reports, Android 


\section{PENDAHULUAN}

Polrestabes (Kepolisian Resort Kota Besar) Makassar adalah institusi negara yang berada di bawah naungan kepolisian daerah Sulawesi Selatan yang memiliki tugas dan tanggung jawab untuk melayani masyarakat kota Makassar dalam proses penanganan berbagai macam permasalahan keamanan dan kriminalitas pada masyarakat kota Makassar.

Tingkat kriminalitas di tengah masyarakat saat ini semakin tahun semakin meningkat, hal ini bisa dilihat dari beberapa tahun terakhir di kota Makassar banyak sekali laporan warga terkait aksi begal, pencurian, pemerkosaan, narkoba dan tindak kekerasan lain.

Adapun tabel data kriminal pada Polrestabes kota Makassar yang di rangkum dari ke 12 jajaran Polsek yaitu :

Tabel 1. Tabel Data Kriminal Polrestabes Makassar

\begin{tabular}{|c|c|c|c|c|}
\hline \multirow{2}{*}{$\mathbf{N}$} & \multirow{2}{*}{$\begin{array}{l}\text { Kasus Tindak } \\
\text { Kriminal }\end{array}$} & \multicolumn{3}{|c|}{ Jumlah Kasus } \\
\hline & & 2014 & 2015 & 2016 \\
\hline 1 & $\begin{array}{l}\text { Pencuri Kendaraan } \\
\text { Bermotor } \\
\text { (CURANMOR) }\end{array}$ & 893 & 1.394 & 410 \\
\hline 2 & Penganiayaan & 235 & 522 & 312 \\
\hline 3 & $\begin{array}{l}\text { Curas (Pencurian } \\
\text { dengan Kekerasan) }\end{array}$ & 124 & 452 & 130 \\
\hline 4 & $\begin{array}{l}\text { Curat (Pencurian } \\
\text { dengan Pemberatan) }\end{array}$ & 231 & 422 & 145 \\
\hline 5 & Pencurian Biasa & 354 & 376 & 289 \\
\hline 6 & $\begin{array}{l}\text { Sajam (Senjata } \\
\text { Tajam) }\end{array}$ & 295 & 360 & 232 \\
\hline 7 & Penggelapan & 238 & 246 & 154 \\
\hline 8 & $\begin{array}{l}\text { Penganiayaan } \\
\text { Ringan }\end{array}$ & 136 & 142 & 112 \\
\hline 9 & Pengeroyokan & 126 & 133 & 98 \\
\hline
\end{tabular}

Keterangan: Data kasus kriminal khusus tahun 2016 di rangkum mulai bulan Januari sampai bulan Juli 2016.
Pada Polrestabes Makassar terdapat 12 jajaran Polsek (Kepolisian Sektor) yaitu Polsek Biringkanaya, Polsek Bontoala, Polsek Makassar, Polsek Mamajang, Polsek Manggala, Polsek Mariso, Polsek Panakkukang, Polsek Rappocini, Polsek Tallo, Polsek Tamalanrea, Polsek Tamalate dan Polsek Ujung Pandang.

Adapun beberapa penelitian yang terkait adalah Sistem Informasi Geografis Daerah Rawan Kriminalitas di Kota Pontianak berbasis Web, pada penelitian ini dibuat sistem untuk memetakan wilayah rawan kriminal yang berada pada kota Pontianak (Septiandari, 2015). Kemudian Penelitian yang berjudul Aplikasi Sistem Informasi Pengolahan Data pada Direktorat Reserse Kriminal Khusus Polda Sumbar, pada penelitian ini menjelaskan mengenai penyajian sebuah format laporan tentang penyidikan perkara tindak pidana kepolisian Republik Indonesia ("Janero Kennedy,2013). Selanjutnya penelitian yang berjudul Metode User Centered Design (UCD) Dalam Perancangan Sistem Informasi Geografis Pemetaan Tindak Kriminalitas (Studi Kasus : Kota Manado), pada penelitian ini membahas mengenai perancangan geografis pemetaan tindak kriminal di kota manado dengan menggunakan UCD (User Centered Design) untuk menangkap kebutuhan pengguna (Akay et al., 2016). Selanjutnya penelitian yang berjudul The application of network analysis to criminal intelligence: An assessment of the prospects, pada penelitian ini membahas mengenai peluang bagi penerapan teknik jaringan analitik terhadap masalah-masalah analisis intelijen kriminal, membayar perhatian khusus pada identifikasi kerentanan dalam berbagai jenis organisasi kriminal - dari kelompok teroris untuk jaringan narkotika pasokan (Sparrow, 1991).

Aplikasi adalah penggunaan dalam suatu 
komputer, instruksi atau pernyataan (statement) yang disusun sedemikian rupa sehingga komputer dapat memproses input menjadi output (Jogiyanto,2008).

Google Maps adalah layanan gratis yang diberikan oleh Google dan sangat popular. Google Maps adalah suatu peta dunia yang dapat kita gunakan untuk melihat suatu daerah. Dengan kata lain, Google Maps merupakan suatu peta yang dapat dilihat dengan menggunakan suatu browser (Svennerberg, 2010). Google menyediakan berbagai API (Application Programming Interface) yang sangat berguna bagi pengembang web maupun aplikasi desktop untuk memanfaatkan berbagai fitur yang disediakan oleh Google seperti misalnya: AdSense, Search Engine, Translation maupun YouTube.

Ada banyak API yang disediakan oleh Google, beberapa diantaranya adalah:

1. Language API: untuk memanfaatkan fitur translation yang dimiliki Google.

2. Earth API: memanfatkan fitur yang ada pada Google Earth.

\section{Javascript API}

4. Maps API: memanfaatkan fitur yang ada pada Google Maps.

5. Search API: memanfaatkan fitur pencarian pada Google Search

6. Visualization API: membuat grafik maupun chart dengan Google API

7. YouTube API: memanfaatkan fitur yang ada pada YouTube misalnya untuk pencarian video.

GPS atau Global Positioning System, merupakan sebuah alat atau sistem yang dapat digunakan untuk menginformasikan penggunanya dimana lokasinya berada (secara global) di permukaan bumi yang berbasiskan satelit.
Dimanapun pengguna tersebut berada, maka GPS bisa membantu menunjukan arah. Layanan GPS ini tersedia gratis (Parkinson,1996).

Kriminalitas merupakan segala macam bentuk tindakan dan perbuatan yang merugikan secara ekonomis dan psikologis yang melanggar hukum yang berlaku dalam negara Indonesia serta normanorma sosial dan agama. Dapat diartikan bahwa, tindak kriminalitas adalah segala sesuatu perbuatan yang melanggar hukum dan melanggar norma-norma sosial, sehingga masyarakat menentangnya (Kartono,2009).

Android adalah sistem operasi berbasis Linux yang dirancang untuk perangkat bergerak layar sentuh seperti telepon pintar dan komputer tablet (Safaat, 2015). Android awalnya dikembangkan oleh Android, Inc., dengan dukungan finansial dari Google, yang kemudian membelinya pada tahun 2005. Sistem operasi ini dirilis secara resmi pada tahun 2007, bersamaan dengan didirikannya Open Handset Alliance, konsorsium dari perusahaanperusahaan perangkat keras, perangkat lunak, dan telekomunikasi yang bertujuan untuk memajukan standar terbuka perangkat seluler.

Rancangan yang digunakan adalah UML ( Unified Modelling Language), UML adalah sebuah bahasa yang berdasarkangrafik/gambar untuk memvisualisasi, menspesifikasikan, membangun, dan pendokumentasiandari sebuah sistem pengembangan software berbasis $\mathrm{OO}$ (ObjectOriented). UML tidak hanyamerupakan sebuah bahasa pemograman visual saja, namun juga dapat secara langsungdihubungkan ke berbagai bahasa pemograman, seperti JAVA, C++, Visual Basic, atau bahkan dihubungkan secara langsung ke dalam sebuah object-oriented database (Ritonga, n.d.) 
Adapun rumusan masalah pada penelitian ini adalah bagaimana masyarakat dapat melaporkan tindak kriminal yang terjadi di sekitar mereka tanpa harus datang ke kantor polisi dan bagaimana aparat dapat menerima langsung laporan kriminal dari masyarakat tanpa harus bertemu dan dapat melihat kejadian dari foto yang dikirimkan serta dapat melihat lokasi serta rute-rute kejadian tindak kriminal di wilayah kota Makassar.

Tujuan penelitian ini adalah membuat sebuah aplikasi berbasis android untuk membantu masyarakat untuk dapat melaporkan tindak kriminal yang terjadi di sekitar mereka tanpa harus datang langsung ke kantor polisi dan membantu aparat dapat menerima langsung laporan kriminal dari masyarakat tanpa harus bertemu dan dapat melihat kejadian dari foto yang di kirimkan serta melihat lokasi dan rute-rute kejadian kriminal dengan memanfaatkan teknologi Google Maps Api.

Pada penelitian ini dibuat sebuah aplikasi laporan kriminal yang penerapannya menggunakan tenologi Google Maps Api untuk pelaporan kejadian kriminal, pelapor dapat mengirimkan gambar berupa foto dan lokasi kejadian kriminal kepada petugas kepolisian. Pengiriman lokasi kejadian dapat di tampilkan pada peta Google Maps API, sehingga para petugas kepolisian dapat segera datang ke tempat kejadian kriminal. Pada peta Google Maps Api juga menampilkan rute-rute lokasi kejadian tindak kriminal tersebut. Pelapor dapat mengirimkan laporan kejadian kriminal melalui perangkat smartphone yang berbasis android dan begitu pula untuk petugas kepolisian menggunakan perangkat smartphone, sehingga pelapor dan petugas dapat melaporkan serta menerima laporan kejadian kriminal kapan saja dan dimana saja.

\section{METODE}

Adapun lokasi penelitian adalah berada pada wilayah kota Makassar dengan melibatkan institusi pemerintahan yaitu Polrestabe (Kepolisian Resort Kota Besar) Makassar.

Metode atau teknologi yang digunakan adalah Google Maps API, Google Maps merupakan layanan mapping online yang di sediakan oleh google layanan yang dapat di akses melalui situs http://maps.google.com. Pada situs tersebut sesorang dapat melihat informasi geografis hampir semua wilayah di bumi. Layanan ini interaktif karena didalamnya peta dapat di geser sesuai keinginan pengguna, mengubah tingkat zoom, dan mengubah tampilan peta. Google Maps menyediakan beberapa mode pada tampilan petanya.

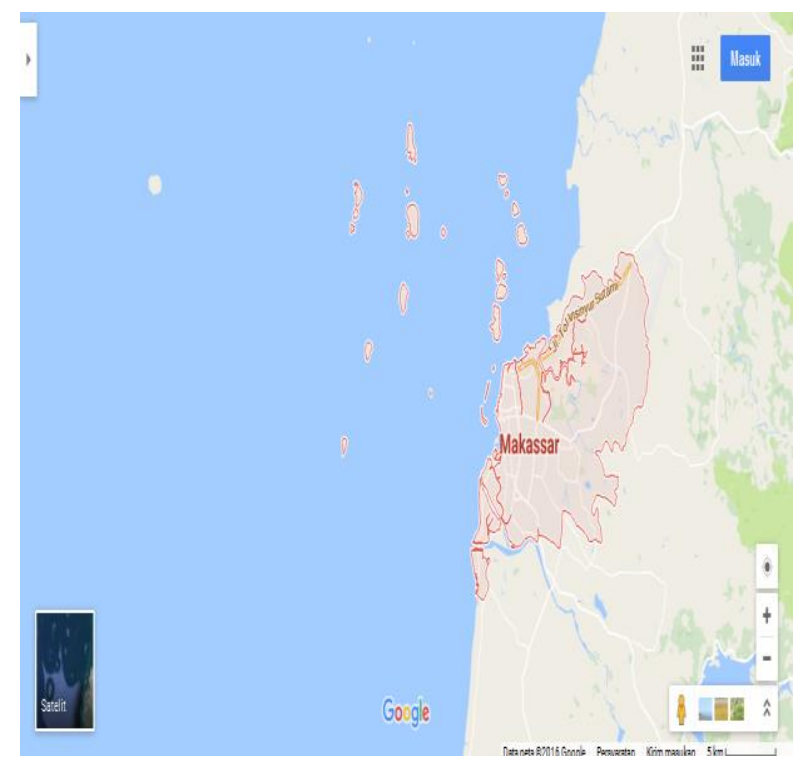

Gambar 1. Tampilan Google Maps

Google Maps dibuat dengan menggunakan kombinasi dari gambar peta, database, serta obyekobyek interaktif yang dibuat dengan bahasa pemrograman HTML, Javascript dan AJAX serta beberapa bahasa pemrograman lainnya. Google Maps API merupakan suatu fitur aplikasi yang dikeluarkan oleh google untuk memfasilitasi 
pengguna yang ingin mengintegrasikan google Maps

ke dalam website masing-masing dengan menampilkan data point milik sendiri.

Sumber data penelitian diperoleh sebagai berikut :

a. Data primer yaitu data-data yang berupa datadata kejadian tindak kriminal yang terjadi pada wilayah Polrestabes Makassar.

b. Data sekunder yaitu berupa literatur, artikel dan beberapa referensi yang berkaitan dan berhubungan dengan kasus-kasus kriminal.

Tahap kegiatan penelitian yang dilakukan sebagai berikut:

a. Pengumpulan data, melakukan proses mengumpulkan data - data yang relevan dengan penelitian dan seperti mencari data-data kasus tindak kriminal, jumlah kasus yang terjadi dan data relevan lainnya.

b. Analisis sistem, yang dilakukan berdasarkan hasil dari tahap pengumpulan data. Analisis dilakukan dengan memperhatikan permasalahan yang ada, tujuan dibangunnya aplikasi laporan kriminal pada Polrestabes Makassar berbasis android dengan memanfaatkan teknologi Google Maps Api, identifikasi input data, serta identifikasi output yang merupakan kebutuhan laporan/tampilan informasi yang diinginkan.

c. Rancangan sistem. Pada tahap ini akan dibuat rancangan aplikasi laporan kriminal pada Polrestabes Makassar berbasis android dengan memanfaatkan teknologi Google Maps Api yang terinci berdasarkan spesifikasi yang diinginkan pada tahap analisis. Pada tahap ini juga dilakukan penetapan standar perencanaan.

d. Pemrograman atau Pembuatan program, yaitu proses pembuatan aplikasi laporan kriminal pada Polrestabes Makassar berbasis android dengan memanfaatkan teknologi Google Maps Api dengan melakukan coding sistem.

e. Pengujian, dilakukan tahap internal testing (unit testing and system testing).

Bahan-bahan yang digunakan untuk menyusun penelitian ini menggunakan data-data sebagai berikut :

a. Data-data kejadian atau kasus tindak kriminal pada Polrestabes Makassar.

b. Data-data wilayah cakupan Polrestabes Makassar.

c. Data-data jumlah kejadian atau kasus tindak kriminal pada Polrestabes Makassar mulai tahun 2014 sampai pertengan tahun 2016.

Alat - alat penelitian yang digunakan untuk mendukung proses pembuatan sistem dalam penelitian ini berupa perangkat keras dan perangkat lunak sebagai berikut :

a. 1 unit laptop acer processor core i3, 520 GB HDD.

b. 2 unit perangkat smartphone.

c. Software eclipse.

d. Dreamweaver.

e. Wamp 5.

f. Alat Perancangan UML ( Unified Modelling Language )

Teknik Pengujian sistem yang digunakan adalah teknik pengujian black box, black box yaitu teknik pengujian yang digunakan untuk menguji fungsional terhadap sistem baik itu fungsi sistem maupun tehadap tombol-tombol dari sistem tersebut (Simarmata, n.d.).

Selanjutnya dilakukan pengujian untuk menguji aspek availability yaitu pengujian sistem yang dapat bekerja selama 24 jam perhari, reliability yaitu mengecek link-link informasi yang terkait dengan 
laporan kriminal pada polrestabes makassar, mengupdate informasi yang terkait dengan laporan ergonomy yaitu memberikan desain yang menari dan kriminal yang ditampilkan pada Google Maps Api, nyaman bagi untu pengguna, portability yaitu sistem safety dan security yaitu keamanan dari akun sistem mampu di jalankan pada berbagai jenis browser yang ada pada admin dan juga akun pada masyarakat untuk admin, dan pada perangkat smartphone, sebagai pelapor dan akun para petugas kepolisian memory yaitu apakah membutuhkan penyimpanan Arsitektur sistem atau gambaran umum dari yang besar, response time yaitu sistem dapat selalu sistem yang di buat pada penelitian ini adalah :

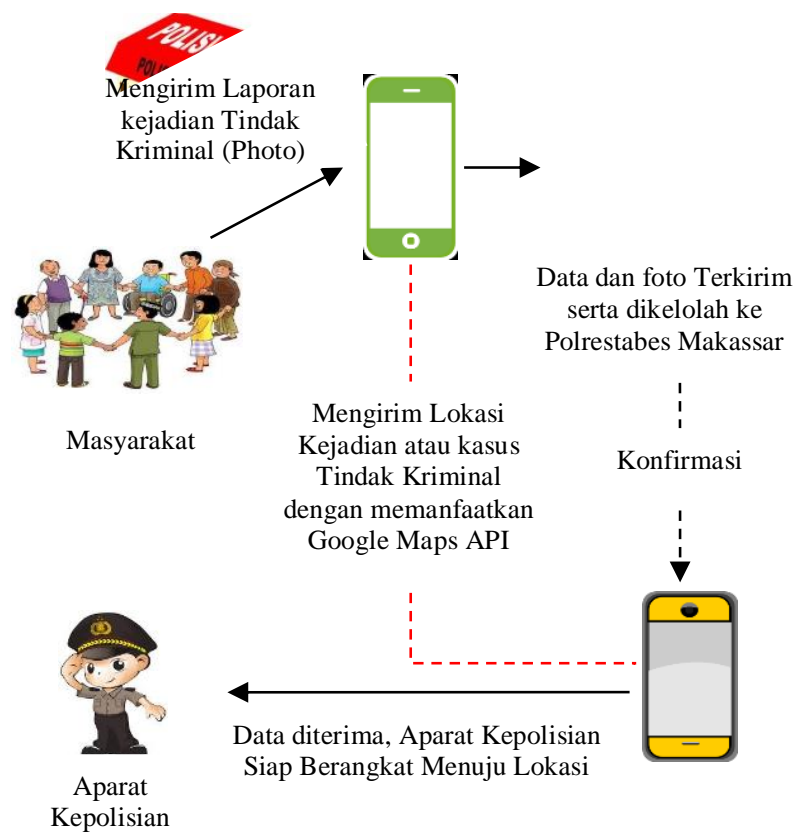

Gambar 2. Arsitektur Sistem

Pada gambar 1 menjelaskan mengenai arsitektur dari sistem aplikasi laporan kriminal, pada arsitektur tersebut masyarakat mengirimkan laporan dalam bentuk kejadian atau kasus tindak kriminal dengan menggunakan perangkat smartphone Android, data laporan yang di kirimkan tersebut akan di kirim kepada Polrestabes Makassar kemudian data tersebut di kelolah dan di konfirmasi kepada aparat kepolisian yang bersiaga pada wilayah kota Makassar kemudian masyarakat mengirimkan lokasi kejadian tersebut sehingga lokasi kejadian tersebut dapat dilihat dengan Google Maps.

\section{HASIL DAN PEMBAHASAN}

Adapun hasil dan pembahasan dari penelitian yang telah dilaksanakan ditunjukkan pada gambar 3 menjelaskan mengenai use case diagram sistem pemanfaatan Google Maps Api untuk laporan kriminal berbasis android pada Polrestabes Makassar. Terdapat 3 aktor yaitu aktor masyarakat, aparat kepolisian dan admin Polrestabes kota Makassar, kemudian kegiatan yang dilakukan pada aktor masyarakat adalah login, registrasi pengguna, melihat status laporan, mengambil gambar kejadian tindak kriminal dan mengirim laporan, gambar atau photo serta lokasi kejadian. Aktor admin Polrestabes Makassar melakukan kegiatan login, mengelolah 
data laporan tindak kriminal kemudian menerima notifikasi laporan kriminal yang sudah di memverifikasi laporan serta mengirimkan notifikasi verifikasi oleh pihak admin Polrestabes Makassar laporan setelah hasil laporan tersebur di verifikasi. kemudian menampilkan lokasi kejadian tindak Aktor aparat kepolisisan melakukan kegiatan kriminal pada Google Maps Api.

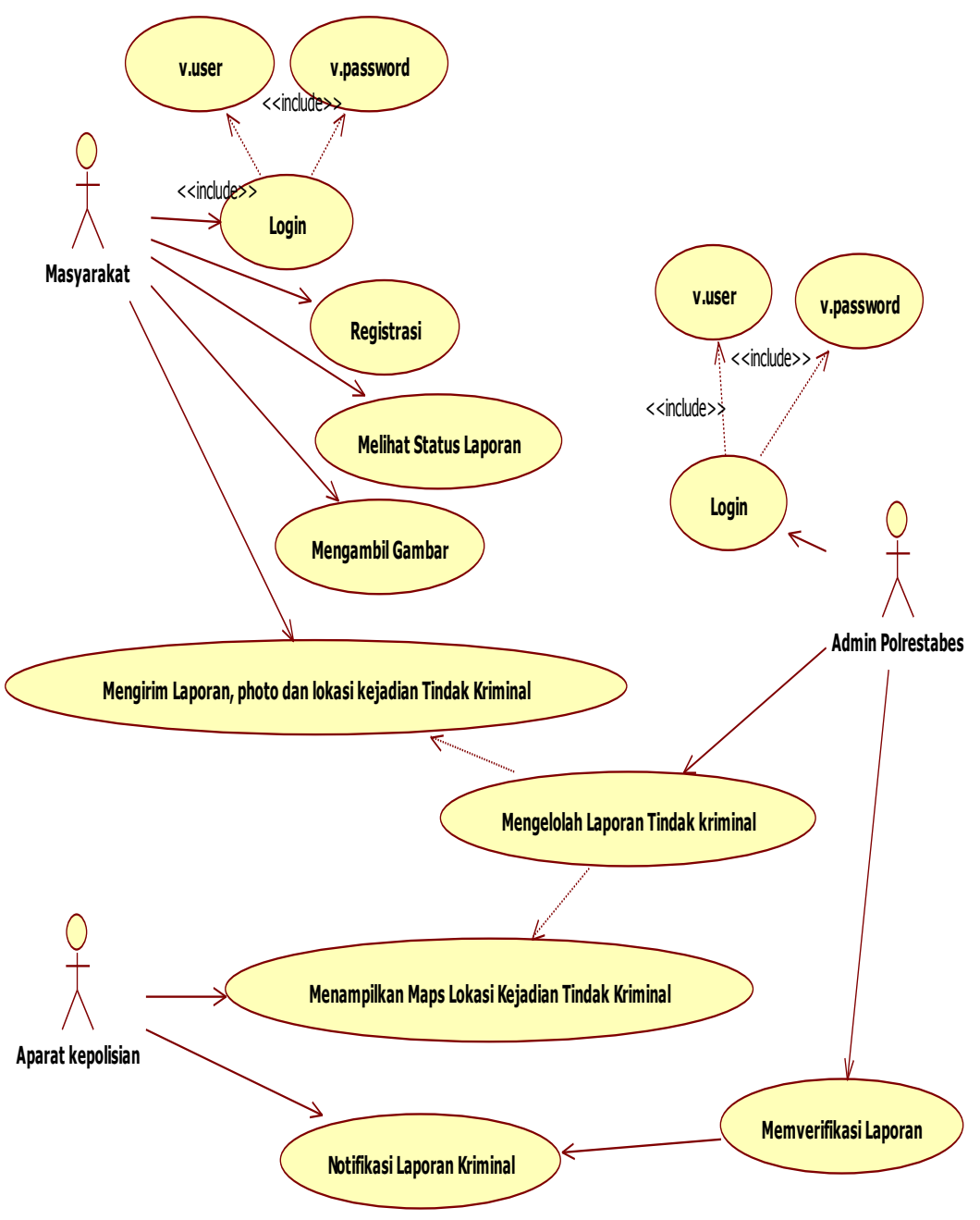

Gambar 3. Use Case Diagram Sistem 
a. Sequence Diagram Proses Pelaporan Kejadian Tindak Kriminal

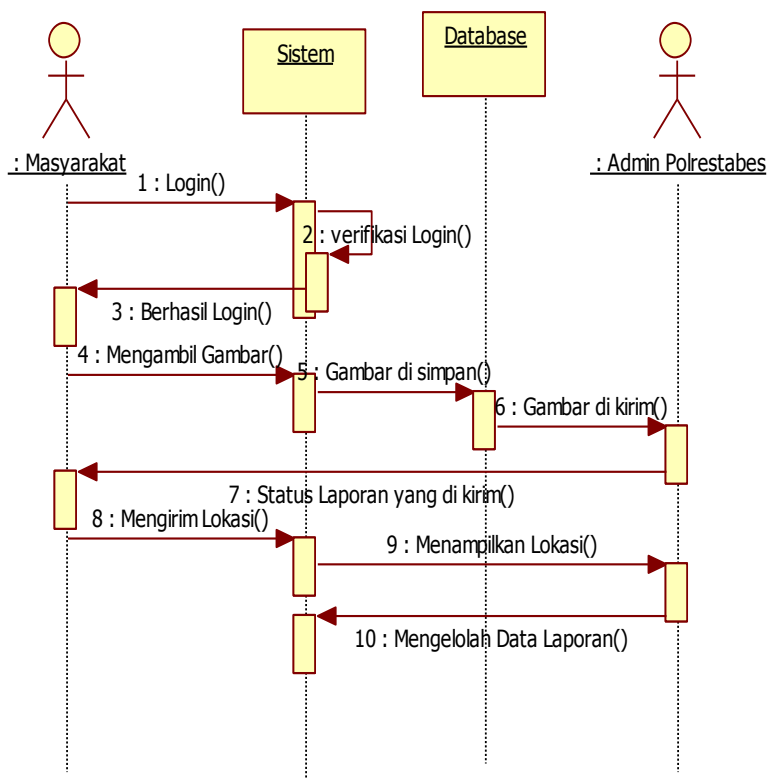

Gambar 4. Sequence Diagram Sistem Proses Pelaporan Kejadian Tindak Kriminal

Pada gambar 4 menjelaskan mengenai sequence diagram pada proses pelaporan kejadian tindak kriminal, pada kegiatan tersebut aktor masyarakat berinteraksi dengan object system, database dan aktor admin porlestabes. Selanjutnya pada gambar 5 menjelaskan sequence diagram pada proses notifikasi laporan kejadian tindak kriminal kepada aparat kepolisian yang berada di lapangan, pada proses kegiatan tersebut data di verifikasi terlebih dahulu oleh admin Polrestabes Makassar sebelum mengirimkan notifikasi tersebut kepada aparat yang berada di lapangan, kemudian data yang telah dikelolah oleh admin berdasarkan laporan dari masyarakat maka aparat dapat melihat gambar atau photo kejadian kriminal dan menampilkan lokasi kejadian pada peta Google Maps Api. b. Sequence Diagram Proses Notifikasi laporan Kriminal

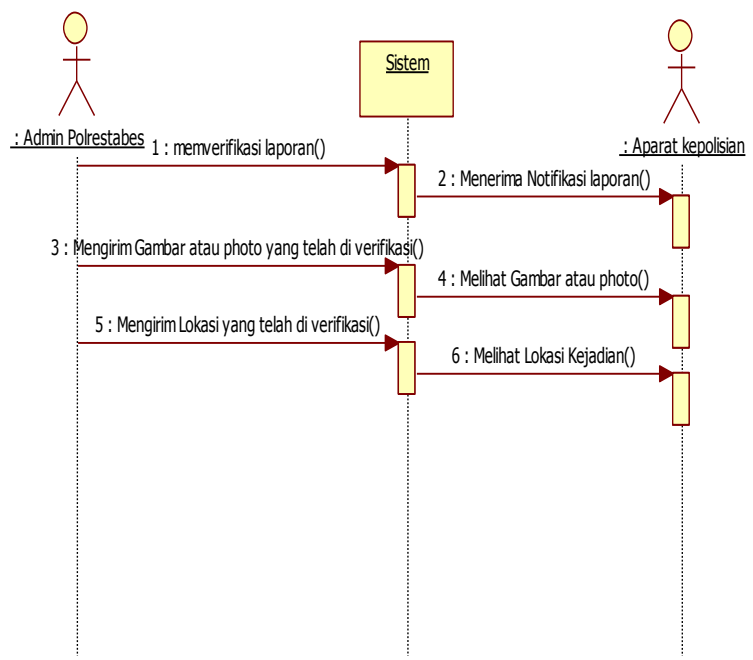

Gambar 5. Sequence Diagram Proses Notifikasi Laporan Kriminal

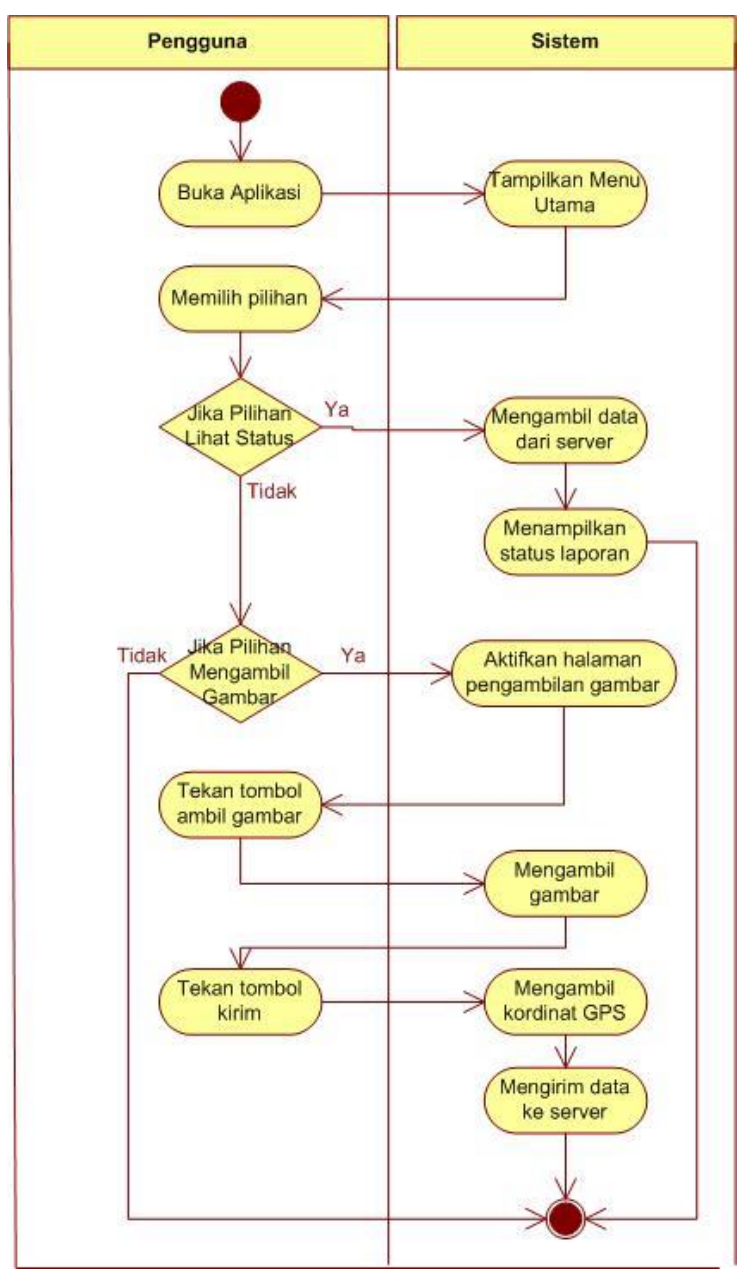

Gambar 6. Activity Diagram Masyarakat Pengguna Sistem 
Pada gambar 6 menjelaskan mengenai aktifitas yang dilakukan aktor masyarakat sebagai pengguna untuk melaporkan kejadian tindak kriminal yang terjadi di sekitar mereka.

c. Activity Diagram Aparat Kepolisian Dilapangan

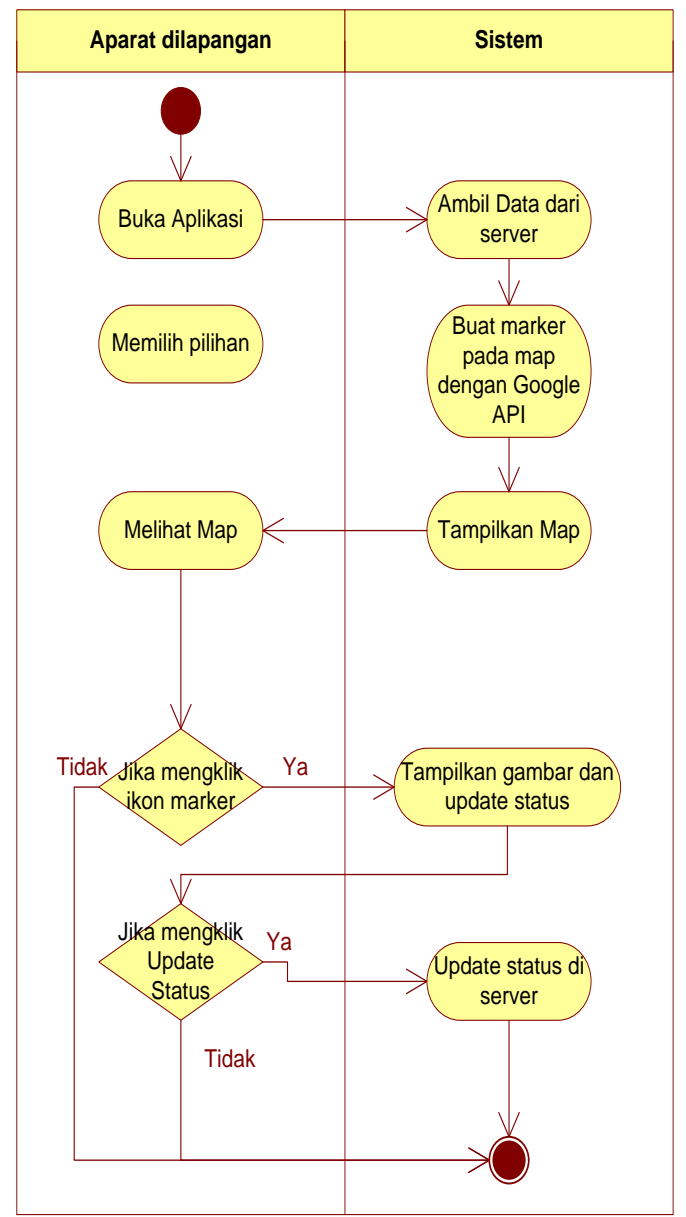

Gambar 7. Activity Diagram Aparat Kepolisian Dilapangan

Pada gambar 7 menjelaskan mengenai aktifitas dari aktor aparat kepolisian sebagai petugas lapangan yang menerima notifikasi laporan kriminal dari masyarakat yang telah dikelolah dan di verifikasi oleh admin Polrestabes Makassar. d. Tampilan Login Admin Polrestabes Sistem Web

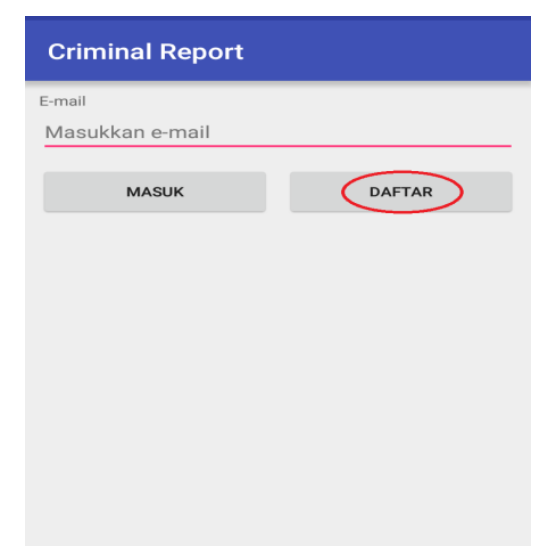

Gambar 8. Login Admin Polrestabes

Pada gambar 8 menjelaskan mengenai tampilan halaman login pada halaman admin Polrestabes yang dijalankan pada sistem web.

e. Tampilan halaman Utama Admin Sistem Web

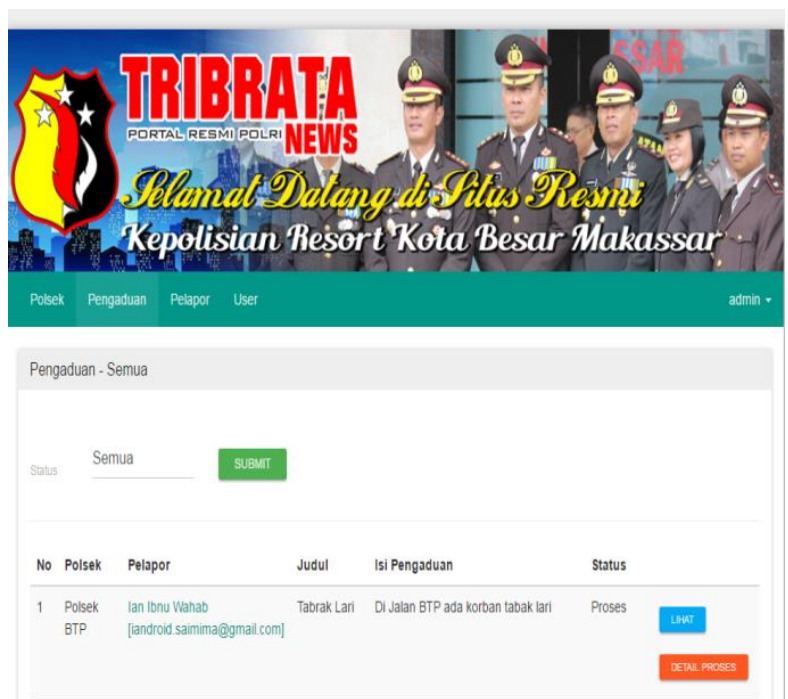

Gambar 9. Tampilan Halaman Utama Admin

Pada gambar 9 menjelaskan tampilan halaman utama dari admin Polrestabes Makassar, pada halaman tersebut segala yang berkaitan dengan kegiatan yang dilakukan oleh admin. 


\section{f. Tampilan Melihat Detail Pengaduan}

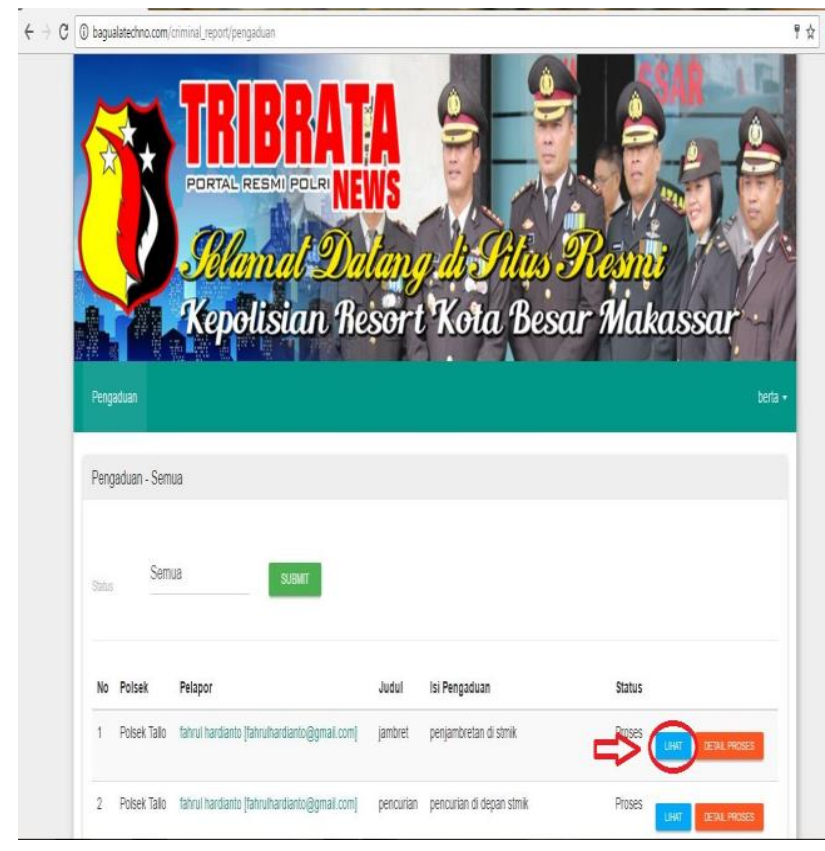

Gambar 10. Tampilan Detail Penganduan

Pada gambar 10 menjelaskan mengenai tampilan detail pengaduan dari masyarakat ke Polrestabes Makassar untuk di kelolah dan di verifikasi terlebih dahulu oleh pihak admin.

\section{g. Tambah Data Polsek}

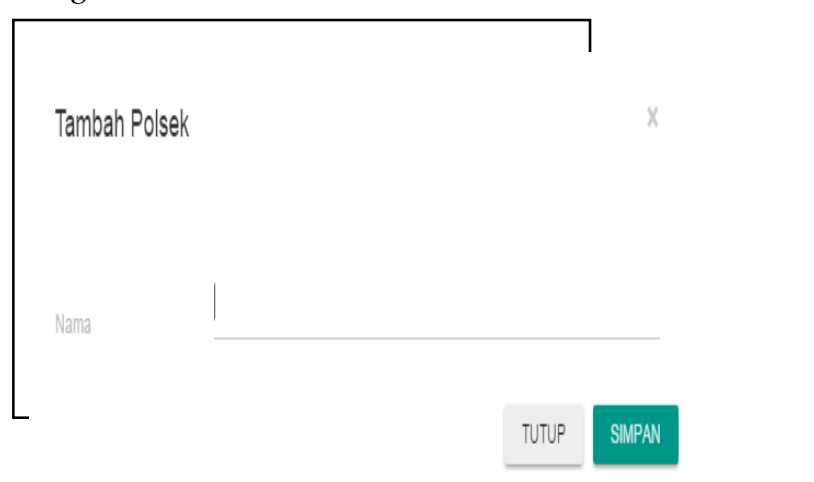

Gambar 11. Tambah Data Polsek

Gambar 11 menjelaskan mengenai proses tambah data polsek yang berada di bawah naungan Polrestabes Makassar. h. Tampilan Login Pengaduan Sistem Android

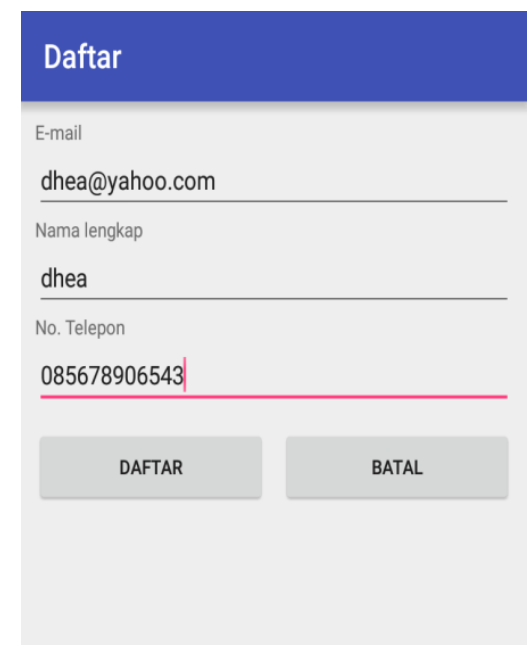

Gambar 12. Login Pengaduan

Pada gambar 12 menjelaskan proses login pengaduan tindak kriminal pada sistem android sebelum login masyarakat atau pelapor dapat registrasi terlebih dahulu.

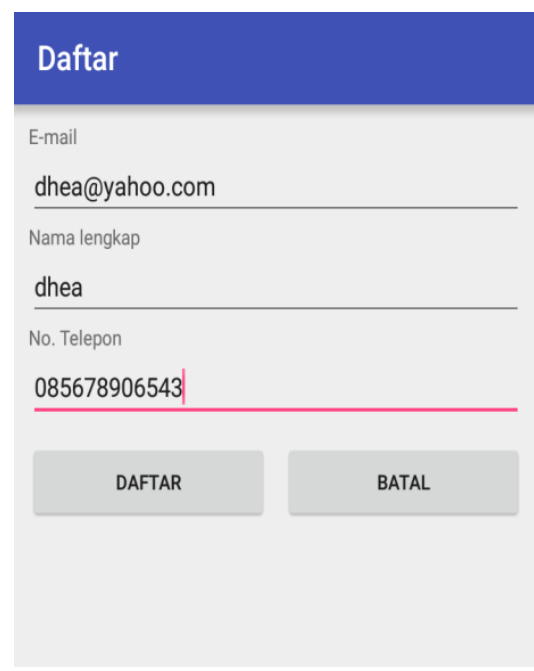

Gambar 13. Registrasi Pelapor

Pada gambar 13 menjelaskan proses daftar atau registrasi sebagai pelapor sebelum melakukan proses pengaduan. 
i. Tampilan Proses Tambah Pengaduan

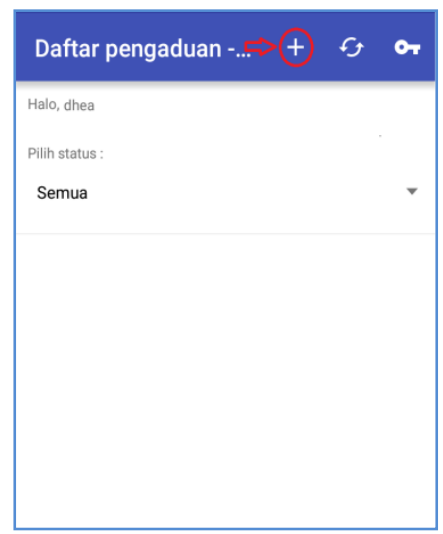

Gambar 14. Proses Tambah Pengaduan

Pada gambar 14 menjelaskan mengenai proses pengaduan tindak kriminal, pada proses ini para pelapor yang sudah registrasi dapat melaporkan kejadian tindak kriminal menggunakan tombol tambah data pengaduan pada aplikasi sistem android.

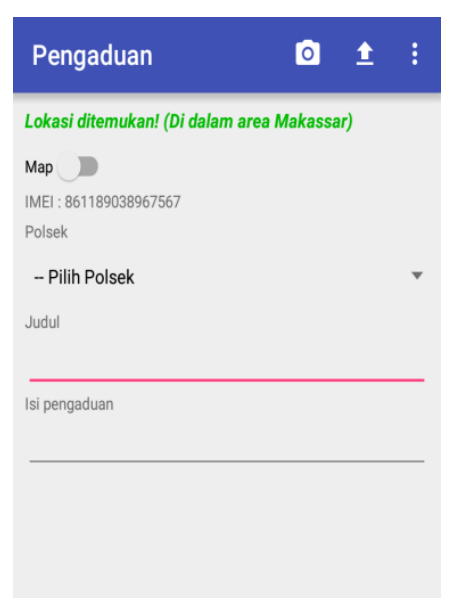

Gambar 15. Proses Mengisi Data Laporan Kriminal

Pada gambar 15 menjelaskan proses mengisi data laporan atau pengaduan kriminal dengan mengirimkan gambar atau photo kejadian, nomor IMEI handphone pelapor dapat mengaktifkan maps.

\section{j. Menampilkan Menaktifkan Maps}

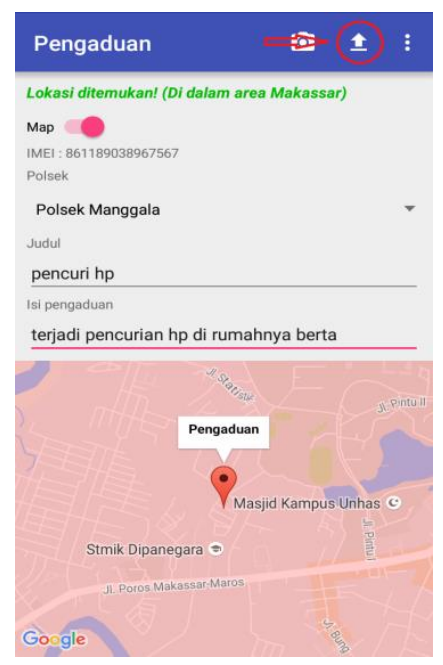

Gambar 16. Mengaktifkan Maps

Pada gambar 16 menjelaskan proses pengaktifan Maps pada aplikasi android pelapor sehingga data lokasi tersebut dapat di kirimkan dan dapat di kelolah serta diverifikasi oleh pihak admin Polrestabes Makassar sebelum di kirim kepada para aparat kepolisian yang ada di lapangan. Proses verifikasi dilakukan untuk memeriksa kembali data laporan yang telah dikirim oleh pihak pelapor.

k. Tampilan Proses Unggah Kejadian Kriminal

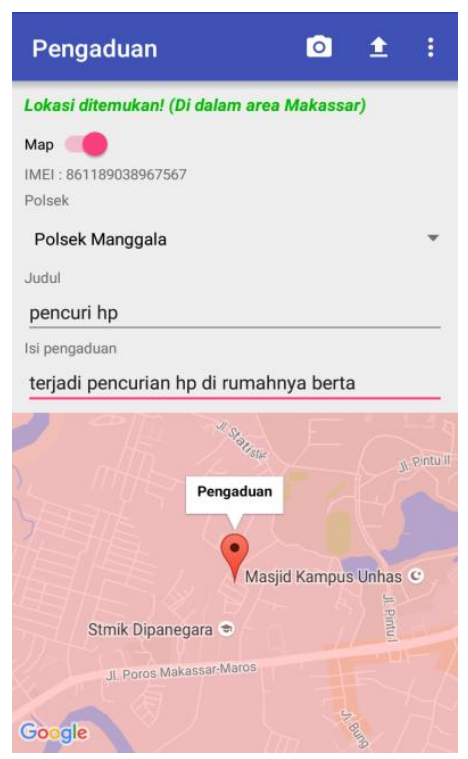

Gambar 17. Proses Uploud Kejadian Kriminal

Pada gambar 17 menjelaskan mengenai proses uploud kejadian kriminal setelah semua 
rangkaian pengisian laporan kriminal telah selesai maka data-data yang telah diinputkan dapat di uploud atau di kirim.

l. Melihat Daftar Pengaduan

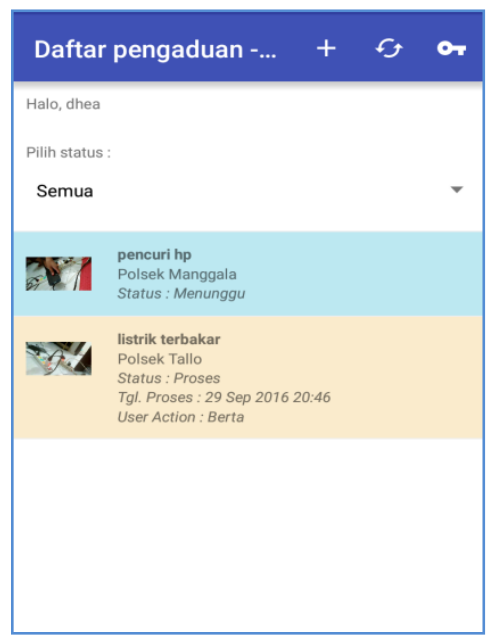

Gambar 18. Menampilkan List Pengaduan

Pada gambar 18 menjelaskan mengenai proses menampilkan list laporan pengaduan.

m. Tampilan Login Aparat Kepolisian sistem Android

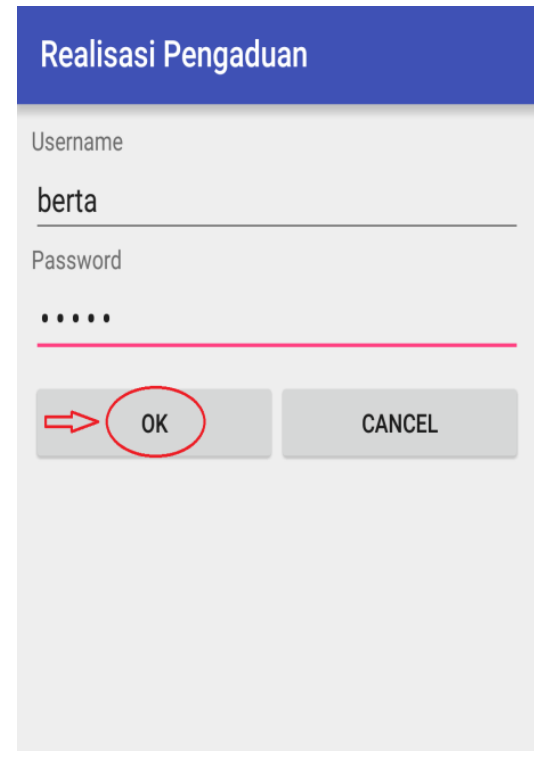

Gambar 19. Login Aparat Kepolisian

Pada gambar 19 menjelaskan mengenai proses login untuk para aparat kepolisian. n. Tampilan Menu Utama Aparat Kepolisian

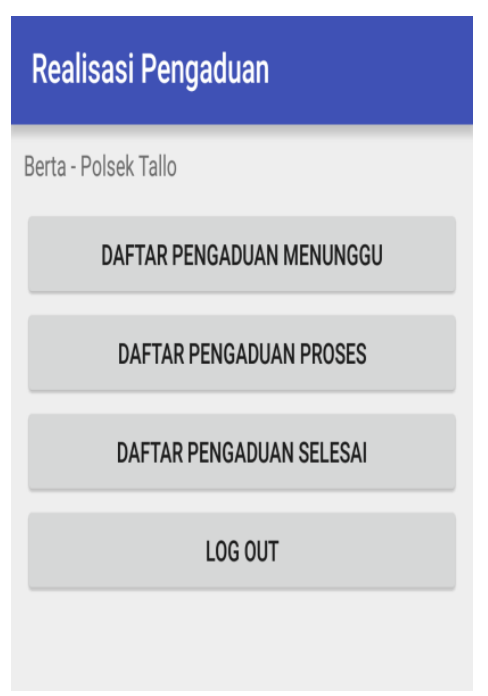

Gambar 20. Tampilan Utama Aparat Kepolisian

Pada gambar 20 menjelaskan tampilan utama dari aplikasi android untuk aparat kepolisian, pada sistem ini aparat kepolisian mendapatkan notifikasi daftar pengaduan menunggu, daftar pengaduan dalam proses dan daftar pengaduan yang selesai di proses.

o. Pengaduan Menunggu

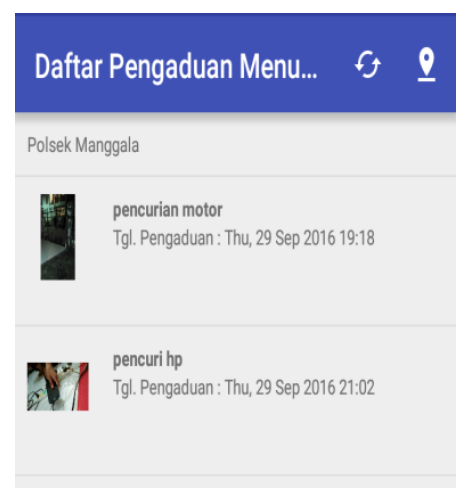

Gambar 21. List Pengaduan Menunggu

Pada gambar 21 memperlihatkan list dari pengaduan yang sedang menunggu untuk di proses. 


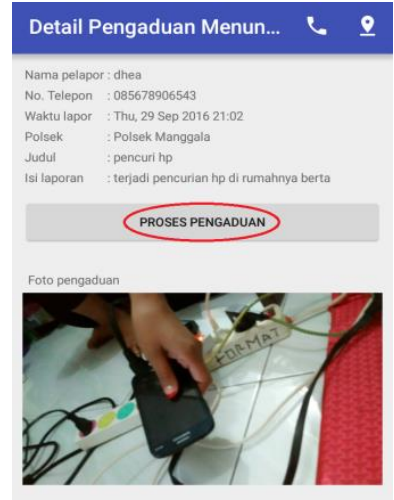

Gambar 22. Detail Pengaduan Menunggu

Pada gambar 22 menjelaskan proses detail pengaduan, pada proses ini aparat kepolisian dapat melihat detail pengaduan sebelum mengklik tombol proses pengaduan kejadian tindak kriminal.

p. Tampilan Pengaduan yang Diproses

\section{Daftar Pengaduan Proses if $\underline{\rho}$}

Polsek Manggala

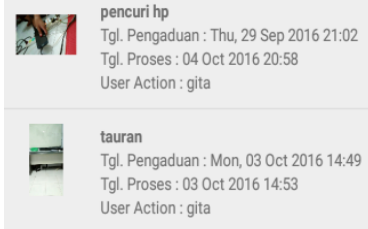

Gambar 23. Aparat Kepolisian Memproses Pengaduan
Pada gambar 23 menjelaskan kegiatan aparat kepolisian melakukan kegiatan memilih pengaduan yang akan di proses.

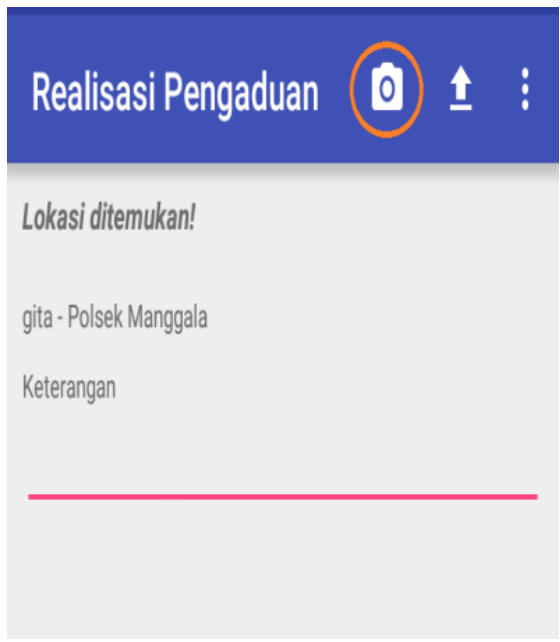

Gambar 24. Mengambil Gambar Hasil Realisasi Pada gambar 24 menjelaskan proses pengambilan gambar atau photo hasil dari realisasi. 
q. Keterkaitan Antara Sistem dengan Google Maps Api

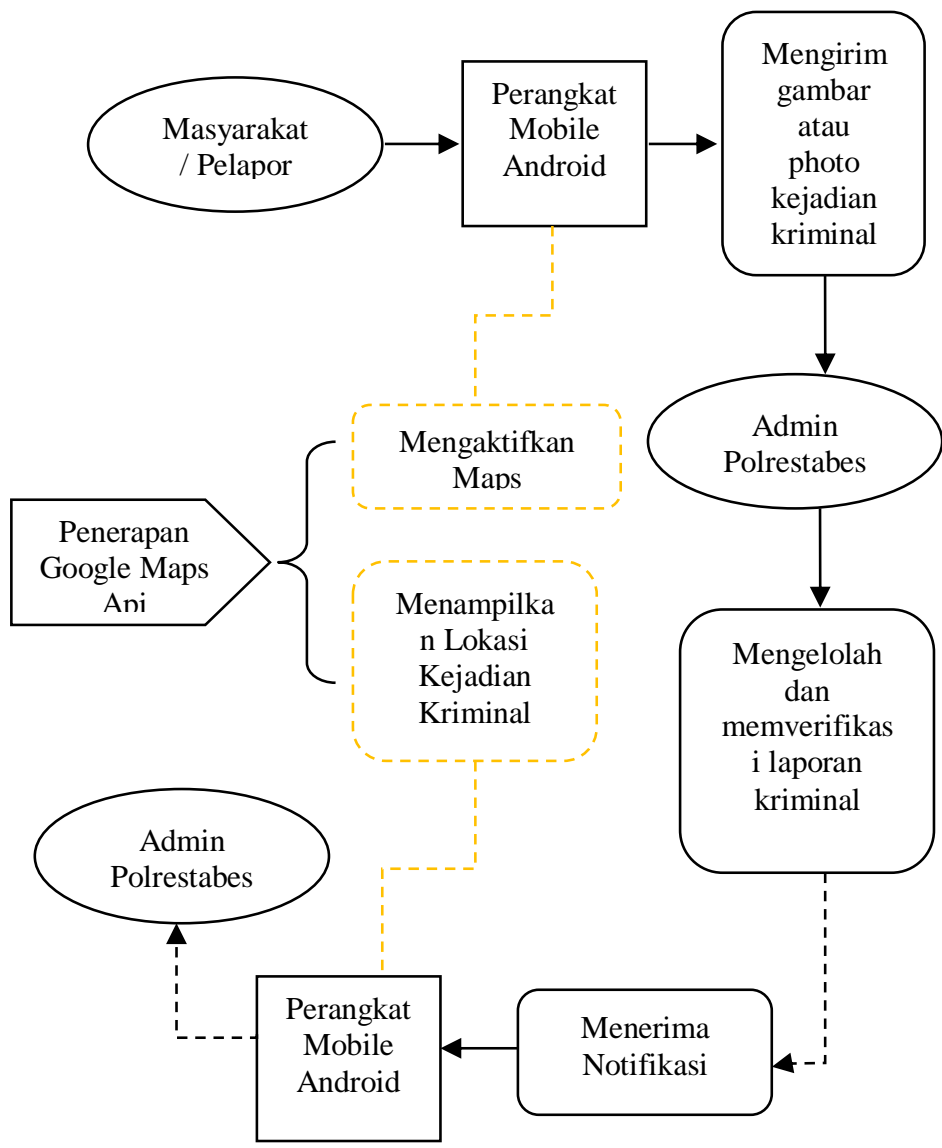

Gambar 26. Keterkaitan Sistem Dengan Google Maps Api

Gambar 26 menjeleskan mengenai keterkaitan antara sistem ddengan Google Maps API, ternologi di terapkan untuk memperilhatkan lokasi kejadian kriminal yang di kirimkan oleh masyarakat sebagai pelapor.

\section{r. Pengujian}

Berdasarkan pengujian Blackbox yang telah dilakukan maka secara umum hasil pengujian aplikasi dapat disimpulkan sebagai berikut :

Tabel 2. Pengujian Blackbox

\begin{tabular}{|c|c|c|c|}
\hline No & Skenario Pengujian & Hasil yang diharapkan & Kesimpulan \\
\hline 1 & $\begin{array}{l}\text { Login Admin } \quad \text { Polrestabes } \\
\text { Makassar }\end{array}$ & $\begin{array}{l}\text { Berhasil Login ke dalam admin } \\
\text { siste web }\end{array}$ & Valid \\
\hline 2 & $\begin{array}{l}\text { Login Pengguna yaitu masyarakat } \\
\text { sebagai pelapor kejadian kriminal }\end{array}$ & $\begin{array}{l}\text { Berhasil Login kedalam sistem } \\
\text { android } \\
\text { pengguna/pelapor }\end{array}$ & Valid \\
\hline 3 & $\begin{array}{l}\text { Login sistem android sebagai } \\
\text { aparat kepolisian }\end{array}$ & $\begin{array}{l}\text { Berhasil masuk ke sistem } \\
\text { sebagai aparat kepolisian yang } \\
\text { berada di lapangan }\end{array}$ & Valid \\
\hline 4 & Memilih menu tambah data baru & $\begin{array}{l}\text { Berhasil menambahkan data } \\
\text { polsek yang baru }\end{array}$ & Valid \\
\hline 5 & Memilih menu edit data & Berhasil mengubah data polsek & Valid \\
\hline
\end{tabular}




\begin{tabular}{clllc}
\hline No & \multicolumn{1}{c}{ Skenario Pengujian } & \multicolumn{2}{c}{ Hasil yang diharapkan } & Kesimpulan \\
\hline 6 & Memilih menu hapus data & \multicolumn{2}{c}{$\begin{array}{l}\text { Berhasil menghapus data polsek } \\
\text { Berhasil Menambahkan Data }\end{array}$} & Valid \\
7 & $\begin{array}{l}\text { Memilih Tombol Data Pengaduan } \\
\text { pengaduan } \\
\text { Berhasil menguploud data } \\
\text { pengaduan } \\
\text { Memilih Tombol Uploud }\end{array}$ & Valid \\
& $\begin{array}{l}\text { Pengaduan } \\
9\end{array}$ & $\begin{array}{l}\text { Memilih detail pengaduan menampilkan detail } \\
\text { produk }\end{array}$ & Valid \\
10 & $\begin{array}{l}\text { Memilih Icon Foto untuk } \\
\text { mengambil photo atau gambar }\end{array}$ & $\begin{array}{l}\text { Berhasil menyimpan data } \\
\text { gambar atau photo }\end{array}$ & Valid \\
\hline
\end{tabular}

Tabel 3. Pengujian Non Fungsional

\begin{tabular}{|c|c|c|c|}
\hline No & Parameter Pengujian & Hasil yang diharapkan & Keterangan \\
\hline 1 & Availability & $\begin{array}{c}\text { Sistem dapat berjalan selama } 24 \\
\text { jam per hari }\end{array}$ & Sukses \\
\hline 2 & Realibility & $\begin{array}{l}\text { Link yang berkaitan dengan } \\
\text { informasi detail kejadian } \\
\text { kriminal dapat di akses }\end{array}$ & Sukses \\
\hline 3 & Ergonomy & $\begin{array}{l}\text { Desain sistem yang menarik dan } \\
\text { nyaman bagi pengguna yaitu } \\
\text { untuk admin, user masyarakat } \\
\text { pelapor dan aparat kepolisian. }\end{array}$ & Sukses \\
\hline 4 & Portability & $\begin{array}{l}\text { Untuk admin dapat menjalankan } \\
\text { sistem pada berbagai jenis } \\
\text { browser, sedangkan untuk } \\
\text { aplikasi android dapat di } \\
\text { jalankan pada mulai android 4.0. }\end{array}$ & Sukses \\
\hline 5 & Memory & $\begin{array}{l}\text { Membutuhkan memory yang } \\
\text { tidak terlalu besar pada admin } \\
\text { namun untuk pengguna sistem } \\
\text { android memerlukan memory } \\
\text { yang besar karena terdapat foto } \\
\text { yang di kirim. }\end{array}$ & Sukses \\
\hline 6 & Response Time & $\begin{array}{l}\text { Sistem mampu mengupdate } \\
\text { informasi terbaru rata-rata } \\
\text { waktu } 10 \text { detik }\end{array}$ & Sukses \\
\hline 7 & Safety / Security & $\begin{array}{l}\text { Akun masing-masing pengguna } \\
\text { sistem menggunakan enkripsi } \\
\text { data }\end{array}$ & Sukses \\
\hline
\end{tabular}

\section{PENUTUP}

Adapun kesimpulan dari penelitian yang telah dilaksanakan adalah dengan adanya aplikasi tersebut maka masyarakat dapat melaporkan tindak kriminal yang terjadi di sekitar mereka tanpa harus datang ke kantor polisi dan memudahkan para aparat kepolisian untuk melihat laporan kriminal dari masyarakat dengan melihat foto/gambar dan lokasi kejadian kriminal tersebut serta dapat menampilkan rute-rute lokasi kejadian tindak kriminal yang ada pada wilayah polrestabes Makassar. Kemudian berdasarkan pengujian fungsional maka di peroleh hasil yang valid, sistem telah berjalan sesuai dengan hasil test factor. Selanjutnya pada pengujian non fungsional berdasarkan aspek availability maka 
sistem dapat berjalan selama 24 jam, reability yaitu link-link pada sistem dapat di akses, ergonomy yaitu memiliki desain dan tampilan yang menarik, portability yaitu sistem untuk admin dapat di buka pada browser manapun sedangkan untuk pengguna dapat dijalankan pada sistem operasi android mulai versi 4.0, memory yaitu membutuhkan memory yang tida terlalu besar pada admin namun pada pengguna memerlukan memory yang besar karena ada pengiriman foto atau gambar, response time yaitu dapat mengupdate informasi dalam waktu 10 detik dan safety/security yaitu password untuk user digunakan enkripsi agar data yang ada pada sistem laporan kriminal dengan menerapkan Google Maps Api tidak dapat di tembus oleh pihak luar.

Adapun saran untuk pengembangan peneltian tersebut adalah sebaiknya untuk menampilkan lokasi kejadian kriminal di gunakan motede algoritma yang relevan untuk perbandingan jarak lokasi kejadian kriminal sehingga dapat menentukan rute lokasi kejadian kriminal secara real time.

\section{UCAPAN TERIMA KASIH}

Terima kasih kepada seluruh jajaran Institusi Polrestabes Makassar yang telah memberikan kesempatan dan informasi baik secara langsung ataupun tidak langsung sehingga penulis dapat melakukan dan melaksanakan penelitian ini. Begitu juga kepada pihak-pihak yang terkait dan telah membantu proses penelitian ini mulai dari pengumpulan data sehingga laporan hasil penelitian ini dapat terselesaikan.

\section{DAFTAR PUSTAKA}

Akay, Y.V., Santoso, A.J., Rahayu, F.L.S., 2016. Metode User Centered Design (UCD) Dalam Perancangan Sistem Informasi Geografis Pemetaan Tindak Kriminalitas (Studi Kasus : Kota Manado). Pros. Semin. Nas. ReTII 0.

Janero Kennedy, 2013, Sistem Informasi Pengolahan Data Pada Direktorat Reserse Kriminal Khusus Polda Sumbar

Publikasi_10.12.5176.pdf, n.d

Jogiyanto.(2008), Analisi dan Desain Sistem Informasi : Pendekatan Terstruktur Teori dan Praktek Aplikasi Bisnis. Yogyakarta :Andi.

Kartono, K. (2009). Patologi sosial jilid 1. Jakarta: Raja Grafindo Persada.

Parkinson, 1996, Global Positioning System: Theory and Applications, American Institute of Aeronautics and Astronautics, Washington D.C.

Ritonga, P., n.d. Pengertian Unified Modeling Language ( UML ) dan Modelnya Menurut Pakar

Safaat, N., 2015. Android: Pemrograman Aplikasi Mobile Smartphone dan Tablet PC Berbasis Android, Revisi Kedua. Informatika.

Simarmata, J., n.d. Rekayasa Perangkat Lunak. Penerbit Andi.

Septiandari, S.A., 2015. Sistem Informasi Geografis Daerah Rawan Kriminalitas Di Kota Pontianak Berbasis Web. J. Sist. Dan Teknol. Inf. JustIN 1.

Sparrow, M.K., 1991. The application of network analysis to criminal intelligence: An assessment of the prospects. Soc. Netw. 13, 251-274. doi:10.1016/0378 8733(91)90008-H

Svennerberg, G., 2010. Beginning Google Maps API 3. Apress. 